\section{International Scientific Journal Theoretical \& Applied Science}

p-ISSN: 2308-4944 (print)

e-ISSN: 2409-0085 (online)

Year: 2016

Issue: 1

Volume: 33

Published: $30.01 .2016 \quad$ http://T-Science.org
Talantbek Tolibdjanovich Madumarov

$\mathrm{PhD}$ in law, Docent

Head of the "National idea, basis of spirituality and law education" department

The Andijan State University

Andijan, Uzbekistan

naumenko06@mail.ru

SECTION 32. Jurisprudence.

\title{
SOME ASPECTS OF THE ORGANIZATIONAL AND LEGAL BASIS FOR MICROFINANCE (ON EXAMPLE OF UZBEKISTAN AND SOME OF THE CIS COUNTRIES)
}

Abstract: In this article some aspects of the organizational and legal basis of microfinance on the example of the Republic of Uzbekistan and the CIS countries are considered.

Key words: the Republic of Uzbekistan, banking-finance sphere, micro-finance, micro-credit institutions, legal regulation, the CIS.

Language: English

Citation: Madumarov TT (2016) SOME ASPECTS OF THE ORGANIZATIONAL AND LEGAL BASIS FOR MICROFINANCE (ON EXAMPLE OF UZBEKISTAN AND SOME OF THE CIS COUNTRIES). ISJ Theoretical \& Applied Science, 01 (33): 44-46.

Soi: http://s-o-i.org/1.1/TAS-01-33-9 Doi: crossef http://dx.doi.org/10.15863/TAS.2016.01.33.9

From the first days of independence, Uzbekistan has started the implementation of reforms in financial and banking sector. It was formed its own national banking and financial system of the country and created a unique mechanism for providing financial services. These show that while in the international financial system there are indications that various financial gaming and fraudulent competition, Uzbekistan has formed a reliable financial system and going that route. In this regard, the President of Uzbekistan Islam Abduganievich Karimov stated the following: "In the period of global financial and economic crisis the financial and banking system of the country has proved its stability and reliability. At the same time, strengthening this system connected with attraction of the private capital in the banking-financial sector at the expense of formation of legal bases in leasing on the basis of private banks and private property, financial institutions such as insurance companies, credit unions, microfinance organizations. Hence this gives an opportunity to enhance competition and improve the quality of customer service in the market of Bank and other financial services and creates conditions for the development of modern market infrastructure that meets the requirements of the highest international standards" [1].

The reforms of the 90-ies of the last century led to the development of entrepreneurship and economic liberalization and this are, in turn, served to increase the demand for credit resources. However, during this period banking institutions have not yet reached sufficient development and could not provide a service for great part of the population that has not had a stable income and collateral.

Under these conditions, citizens are combining their financial and intellectual resources have formed associations, foundations, and credit institutions called "microfinance institutions".

For the development of microfinance services as additional factors were carried out legislative reform in the CIS countries and adopted new regulations in this period, in almost all the CIS countries have passed laws regarding the civil code, credit unions, microfinance organizations and microcredit.

It should be noted that the emergence of microcredit institutions and acquisition on market of the microfinance services is determined by the distinctive characteristics. This process was observed not efficiency initially formed to credit institutions and instead implement financial assistance of the economic subjects of small business and entrepreneurship, the goal of getting big benefits, and implementation of financial fraud. This, in turn, demanded the extension of the implementation in comparison with the credit unions microcredit institutions and its transformation into the organization, implementing effective financial 
provision of services for business structures. From this point of view, in the early twenty-first century began to form the institution of microcredit as a banking and non-banking institutions, and today's practice shows that the service they provide from the point of view of finance are effective and sustainable.

In this regard, it is to highlight the relevance of the activity of micro credit agencies as nonbanking organizations in the market of financial services.

It should be noted the provision of nonbanking entities or credit institutions unlicensed financial services to the population outside the banking control and according to this, the problem of determining the legality of the provision in different countries has its own characteristics. For example, in the U.S., the activity of some nonbanking organizations denying regulation by the Federal Reserve, argues that the services provided by them to attract and grant funds are not considered bank transaction. For this reason, from the point of view of legality, has developed explanations for the changing of notions (terms) the "commercial debt" and the "contribution" [2, 78 84].

Using the U.S. experience, it is possible to conduct a brief analysis of the role of micro financial institutions in economic development. In the 60-ies of the last century in America began, the Federal program of the "war against poverty" and its focus was on a specially designed credit schemes and models for the financing of small business, representatives of national minorities and other financially insecure groups of citizens. Later there was organized the Department of business development on a widespread implementation of microfinance schemes in practice and to date, these schemes have an important place in the economy of the United States [3].

In Russia and some of the CIS countries banks are not interested in providing services to citizens non-permanent employment and do not receive a regular income, or to persons who are not able to confirm the information on income in installed form. This explains the high risk of lending to this segment of the population and the lack of a single source for determining solvency. In addition to similar customers of the bank in accordance with the standards of the bank have very little income; this provision requires the implementation by credit institutions of labour costs and related organizational costs. The period of these factors deepens the instability of the economic situation increases the risk of non-repayment of funds provided by the bank.

The activity of large companies in underdeveloped systems of microfinance is successfully working in microfinance institutions and provides assistance in raising the economic level and stability of existing social contradictions.

The analysis of legislation of the CIS countries shows that one of the main shortcomings in the existing legislations of the countries is the lack of current regulation of the legal definitions of the "micro" and "micro-services". At the same time, to date for this type of social relations was formulated the main regulatory definitions.

However, the economic and legal definitions of the act on the basis of microfinance services, and due to the presence of inherent qualities are different from other uniform services. When comparing banks with microfinance in the economic sphere distinctive characteristics are the size and number of transactions when using financial services of traditional banking institutions providing services to those sectors of the population who are faced with difficulties, and limiting the scope of service within a defined territory.

Characteristics of microfinance activities of the CIS countries are the following:

First of all, the activity of microfinance organizations is characterized by a special legal regulation on the basis of the legislation of many the CIS countries and is subject to the law on banks and banking activity. Secondly, the microfinance services are separate legal entities - credit unions, pawnshops, organizations formed to carry out this activity and have the potential of microfinance. Thirdly, the microfinance is defined by the normative restriction of the list of provided services. In microfinance, the number of savings and credit operations is limited. Fourthly - the composition of the customer base is adjustable from the point of view of quantity and quality. In Uzbekistan, including some of the CIS countries: Russia, Ukraine, Azerbaijan, Moldova, Kazakhstan microfinance organizations are created on the basis of membership (representation), whereas services is provided only their members. Fifthly -the presence of the distinguishing characteristics in the definition of the procedure for operations of microcredit organizations. In all of the countries of the CIS (countries-members of the CIS) although not clearly, from the point of view of terminology, defined the differences of legislative concepts of banking and microfinance services. Even if it's about deposits or loans there are specific legal differences inherent in microcredit organizations. For example, the contract of bank deposit, concluded between the bank and the citizen is a massive contract, but the contract of bank deposit, concluded by the credit union is not a massive contract, because the range of subjects that used these types of services, namely the members of the association, defined. In accordance with the laws of Moldova and Russia, microfinance services are based on the Regulation "On credit contracts of the civil code", that is, in contrast to banking services are characterized by independent legal regulation. Sixthly - set the maximum amount of the granted credit or a loan. If in the legislation does not define the maximum number of services provided by banks, microfinance organizations in the 
CIS countries the amount of funds is limited. In this regard, to financial services provided by these agencies, uses the term "micro". Seventhly economic norms concerning the simplification of requirements. Unlike banks, which are strictly set by many figures due to small volume and the number of services provided by microfinance institutions, their activities are not fully defined, and regulations are not stringent and in accordance with the rules determined by several parameters. Although many countries in have stringent requirements on the activity of microfinance organizations, banks, these requirements on the requirements to banks is simple. Eighthly - the establishment of the competent authority in the field of monitoring and control. In many member countries of the CIS created a special authority for the monitoring and control over the activity of microfinance organizations. The Central Bank in these countries is not eligible for regulation and supervision of microfinance services [4].

Of course, microfinance services, as a financial activity has distinctiveness in legal settlement and this originality are manifested not only by application to type of activity the term "micro". In this case, the subject of regulatory legislation on microfinance is the social relations arising from the activities of microfinance organizations and the provision of microfinance services.

In accordance with the Article 3 of the Law of the Republic of Uzbekistan "On microfinancing" No.
50 of 15 September 2006, "Microfinancing is an activity that provides microfinance services, microcredit, microdebt, the provision of microleasing in an amount not exceeding the amount set out in Convention with the legislative documents of the microfinance institutions and other microfinance services in accordance with the agreement on provision of services [5].

It says that microfinance is a type of economic activity for the provision of microfinance services. Microfinance service is, in accordance with law, financial operations by microfinance organizations, unlike banks, have a special legal status. The main types of microfinance operations are to attract funds and issuance of loans. This list is not strictly final, depending on the type and characteristics of legal regulation of the organization may be restricted or supplemented. In law may also be included an additional legal description of microfinance services, for example, the maximum amount of debt.

Overall, the legal framework of microfinance activity today needs improvement.

On the basis of the above features is necessary to modernize the legal norms regulating the activity of microfinance organizations as well as improvement of the coherence of the legal mechanism of services provided by microcredit organizations.

\section{References:}

1. Karimov IA (2010) Koncepciya uglubleniya demokraticheskih reform $\mathrm{v}$ strane i razvitiya grazhdanskogo obshchestva. Zakonodatel'naya palata Olij Mazhlis Respubliki Uzbekistan i doklad Dopolnitel'nogo Sobraniya Senata // Narodnoe slovo, november 13, 2010.

2. Semenceva G (1997) Formy finansirovaniya malogo innovacionnogo biznesa v SSHA i Zapadnoj Evrope// Rossijskij ehkonomicheskij zhurnal. 1997. -№5-6.

3. Chernomorova TV (2005) Malyj biznes v SSHA: problemy finansirovaniya// Malyj biznes i regional'noe razvitie $\mathrm{v}$ industrial'nyh stranah. - Moscow: «Prospekt», 2005. - 349 p.

4. Mel'nikov NN (2015) Pravovoe regulirovanie mikrofinansirovaniya v Rossii i stranah SNG / Available:

http://www.ruralcredit.ru/514/518/625/1097/ (Accessed: 10.01.2016).

5. (2006) Zakon Respubliki Uzbekistan «O mikrofinansirovanii», 15.09.2006 / Available: http://lex.uz/pages/getpage.aspx?lact_id=10553 19 (Accessed: 10.01.2016).

6. Hozhiev EH, Samigzhonov F (2006) Bankovskoe pravo Respubliki Uzbekistan: rukovodstvo dlya bakalavriata napravleniya yurisprudencii/ Otvetstvennyj redaktor: d.yu.f., prof. M.H.Rustambaev. -Toshkent: TGYUI, 2006. - pp.3.

7. Rahmonkulov H (2008) Sub"ekty grazhdanskogo prava. - Toshkent: TGYUI, 2008. - 84 p.

8. Yuldashev ZI (2004) Akcionernoe obshchestvo - v kachestve sub"ekta grazhdanskogo prava. Toshkent: TGYUI, 2004. - $121 \mathrm{p}$.

9. Topildiev VR (2011) Teoriticheskie i prakticheskie voprosy organizacionno-pravovyh grazhdanskih otnoshenij. -Toshkent: 2011. - pp. 55-56.

10. Nefedov DV (1994) Pravovoj status kommercheskogo banka: Avtoref. dis... kand. yurid. nauk. - SPb., 1994. - 12 p. 